\title{
A rapid and cheap protocol for preparation of PCR templates in peanut
}

\author{
Chuan Tang Wang \\ Ocean University of China \\ Qingdao 266003, P R China \\ Xiu Zhen Wang \\ Shandong Peanut Research Institute \\ Qingdao 266100, PR China \\ Yue Yi Tang \\ Shandong Peanut Research Institute \\ Qingdao 266100, PR China \\ Jian Cheng Zhang \\ Shandong Peanut Research Institute \\ Qingdao 266100, PR China \\ Shan Lin Yu \\ Shandong Peanut Research Institute \\ Qingdao 266100, PR China \\ Jian Zhi Xu \\ Shandong Peanut Research Institute \\ Qingdao 266100, PR China

\section{Zhen Min Bao*} \\ Ocean University of China \\ Qingdao 266003, PR China \\ Tel: 865328203196 \\ E-mail: zmbao@ouc.edu.cn
}

Financial support: Financial support from the earmarked fund for Modern Agro-industry Technology Research System (MATRS) Peanut Program, MOA, China, China Natural Science Foundation (Grant No. 30300224), 863 New and High Technology Project (Grant No. 2002CCC03200, 2006AA10A114), New and High Technology Innovation Foundation of Shandong Academy of Agricultural Sciences (Grant No. 2006 YCX013), and Young Scientists Foundation of Shandong Academy of Agricultural Sciences (Grant No.2007YQN007) is gratefully acknowledged. We are in debt to Prof Rong Hua Tang for his generosity in providing wild peanuts.

Keywords: DNA extraction, groundnut, PCR, peanut.

Abbreviations: GXAS: Gaungxi academy of agricultural sciences

ITS: internal transcribed spacer

MAS: marker-assisted selection

PCR: polymerase chain reaction

PVP: polyvinylpyrrolidone

SCAR: sequence-characterized region

SSR: simple sequence repeat

This paper describes a simple, low cost and reliable DNA template preparation protocol for polymerase chain reaction (PCR) using immature leaves from peanut seeds or leaves from field-grown plants. The technique may find wide utility in studies involving PCR-based molecular markers, rapid screening for transformants and gene cloning.
Conventional DNA extraction protocols usually involve many steps; for plants species with abundant secondary metabolites, a lengthy procedure of over 10 steps is generally needed (Weising et al. 2005; Sarwat et al. 2006). The cultivated peanut and its wild relatives in the genus Arachis are species with carbohydrates and poly-phenols. Several DNA extraction and purification protocols for

*Corresponding author 


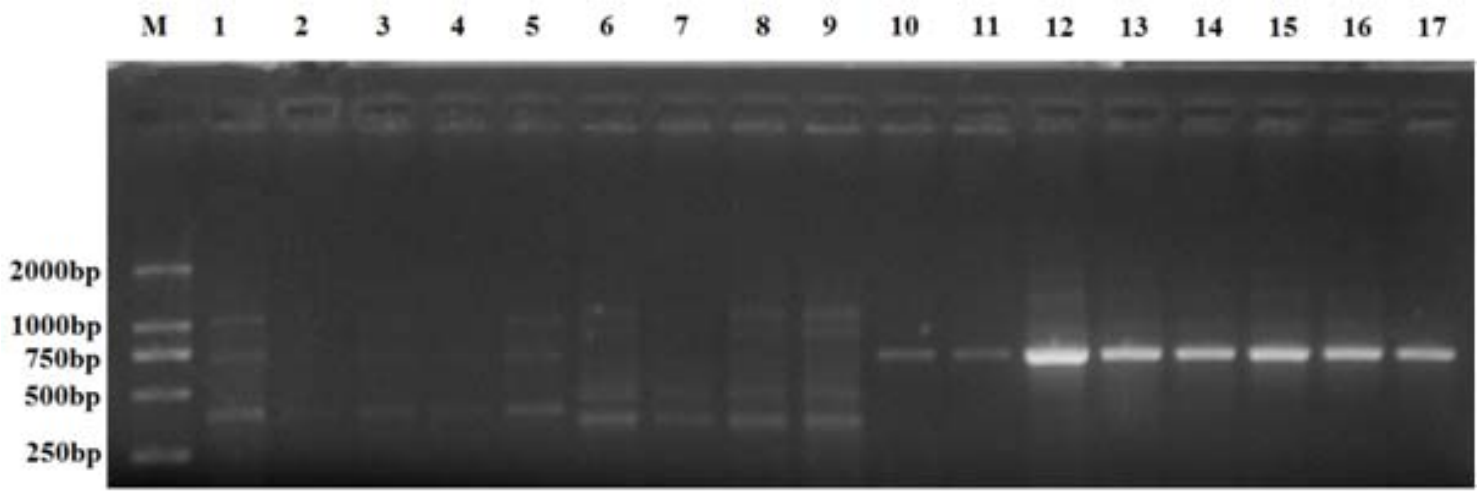

Figure 1. PCR products resolved on a 1.0\% agarose gel. M: Tiangen D2000 DNA marker. The numbers used in the figure were the same as in the first column of Table 1. Genotypes, source of leaflets, primer pairs and treatments were listed in Table 1.

peanut have been published and proved competent in restriction digestion and Southern hybridization (Kochert et al. 1991; Choi et al. 1999; Burow et al. 2001; Wang et al. 2002; Chen et al. 2008). However, it is still difficult, within a short period of time, to deal with large number of samples even with sophisticated stainless steel beads and a grinding machine. This inevitably impedes the wide application of marker-based selection and fast screening for transformants in peanut.

Here we described a rapid, simple and cost-effective method for preparation of polymerase chain reaction (PCR) templates for peanut, which may facilitate marker-assisted selection (MAS) and gene mapping using simple sequence repeat (SSR) or sequence-characterized region (SCAR), screening of transgenic peanut plants and homology-based cloning as well.

\section{MATERIALS AND METHODS}

\section{Materials}

For primary evaluation of the protocol, totally 7 peanut genotypes were utilized. These included 3 peanut cultivars (I8B4, Luhua14 and L-1), 2 interspecific derivitives [6-33 (Silihong $\mathrm{x}$ Arachis rigonii) and L7-1 (Silihong $\mathrm{x}$ A. glabrata)] and 1 chemical mutant of L7-1 (m5) (Table 1).

For further evaluation, 8 accessions of peanut wild relatives (field-grown plants), 2 peanut landraces (Yingkousilihong and Xingchengdahuasheng) and an interspecific derivative 1-4 (Silihong x Arachis glabrata) (immature leaflets from seeds) were used (Table 2).

\section{PREPARATION OF PCR TEMPLATES}

When a seed is available, the immature leaflets (embryonic tissue from a non-germinated seed, $2.2 \sim 3.2 \mathrm{mg}$ ) may be used as the starting material. The leaflets were collected and placed into a $1.5 \mathrm{ml}$ Eppendorf tube, and 20, 40 or 60 $\mu \mathrm{l}$ of $0.25 \mathrm{~mol} / \mathrm{L}$ sodium hydroxide $(\mathrm{NaOH})$ was added.
The leaflets were then smashed using a thin-walled PCR tube mounted with a $1 \mathrm{ml}$ pipette tip as a pestle. The mixture was boiled for $30 \mathrm{sec}$. Then 80,160 or $240 \mu \mathrm{l}$ of Tris-HCl (pH 7.6) with5 $\mathrm{mg} / \mathrm{ml}$ of polyvinylpyrrolidone (PVP) (4 times the volume of $\mathrm{NaOH}$ added) was added followed by boiling for $2 \mathrm{~min}$. After centrifugation at 10,000 RPM for $5 \mathrm{~min}$, the supernatant was collected and stored at $4^{\circ} \mathrm{C}$ for use within a week, or stored at $-20^{\circ} \mathrm{C}$ for several months.

Leaves from peanut plants grown in glasshouse or field may also be used, but the unexpanded or freshly expanded leaflets on the apex of branches/stems are most preferable. The unused end (without a tip) of a ball point pen refill was utilized as a hole puncher. The leaf disc $\left(6.5 \mathrm{~mm}^{2}\right)$ thus prepared may be handled using the alkali-lysis protocol, just as immature leaflets from a seed, which was described above.

\section{PCR}

To amplify the internal transcribed spacer (ITS) of peanut, $2 \mu \mathrm{l}$ DNA template was used in a $25 \mu \mathrm{l}$ reaction using Tiangen 2 x Taq PCR MasterMix (Tiangen Biotech) and the primer $\mathrm{a}$ and primer $\mathrm{b}$ as recommended by Wang et al. (1999). The PCR profile consisted of a pre-denaturation of $94^{\circ} \mathrm{C}$ for $3 \mathrm{~min}, 35$ cycles of $94^{\circ} \mathrm{C}$ for $50 \mathrm{sec}, 55^{\circ} \mathrm{C}$ for 1 min, and $72^{\circ} \mathrm{C}$ for $1.5 \mathrm{~min}$, and a final extension of $7 \mathrm{~min}$.

To amplify the $\beta$-tubulin gene-derived DNA regions, Tiangen $2 \times$ Taq PCR MasterMix and primer pairs TBPfex1/TBPrex1 and TBPfin2/TBPrin2 were used. The primer pairs and PCR profile were the same as Breviario et al. (2007).

\section{Agarose gel electrophoresis of PCR products}

After amplification was complete, $3 \mu \mathrm{l}$ of liquid from the PCR tube were run on a $1.0 \%$ agarose gel $(1 \times \mathrm{TBE})$ for 40 min at $100 \mathrm{~V}$, and the gel was subsequently stained using 


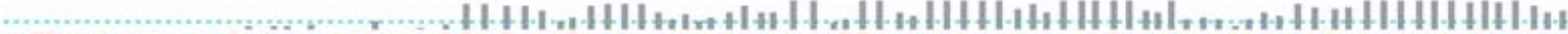

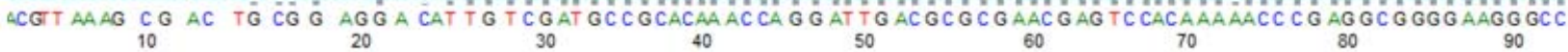

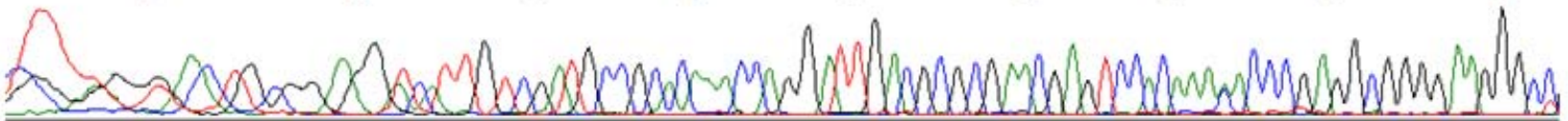

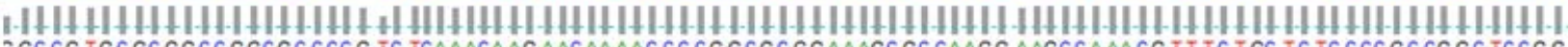

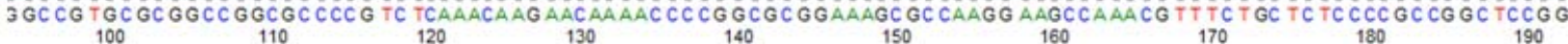

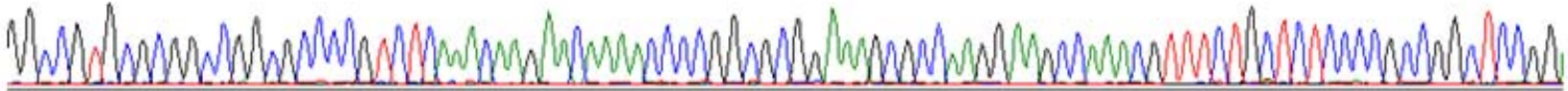
||-||-HНHН.

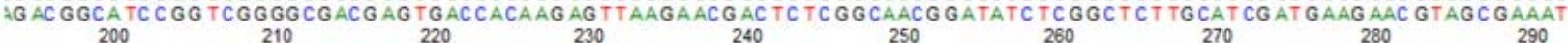

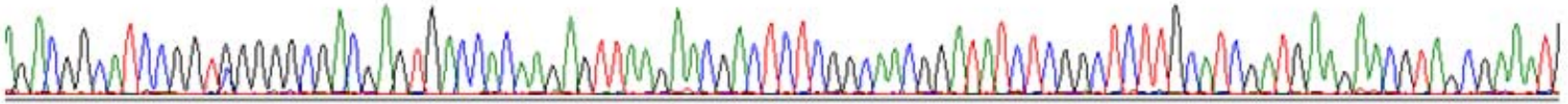
НННННННННННННННННННННННННННННННННННННННННННННННН.НННННННННН

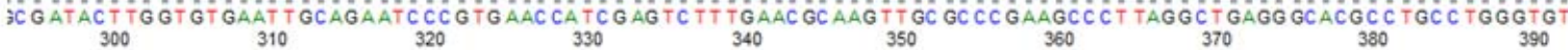

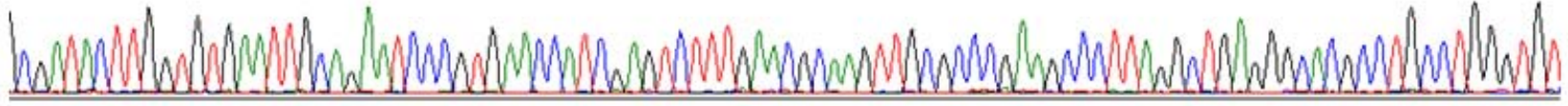

Figure 2. ITS of A. duranensis PI263133 (A19).

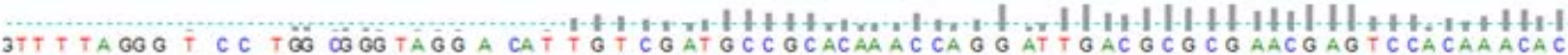

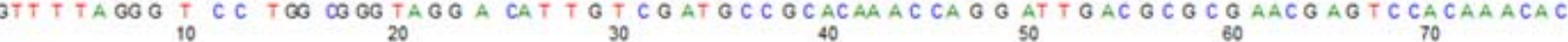

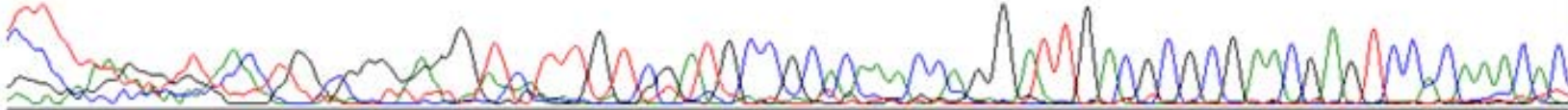

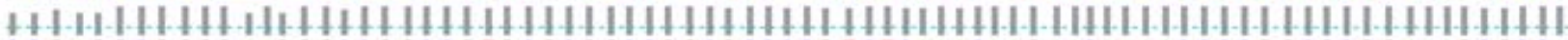

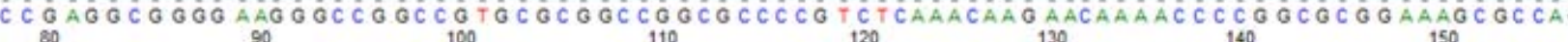

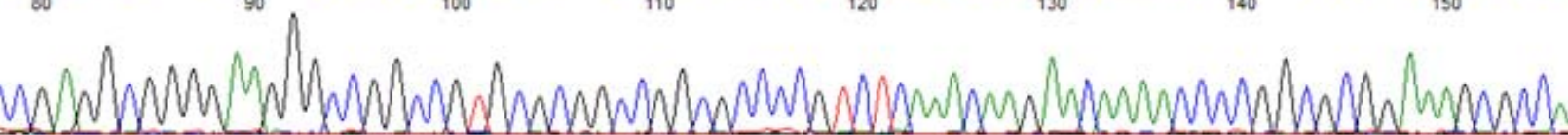

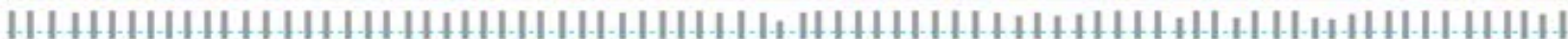

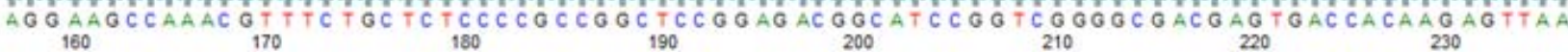

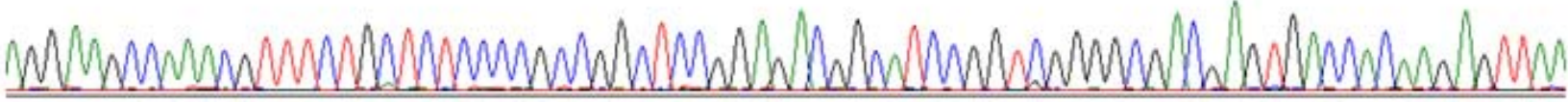

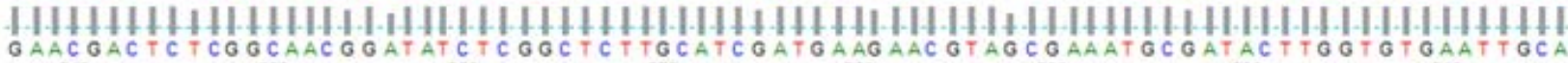

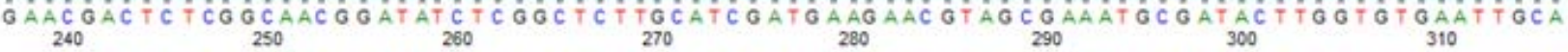

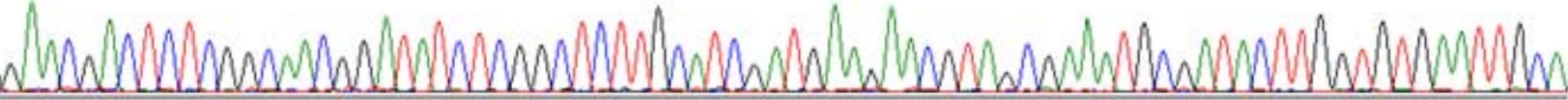

Figure 3. ITS of A. pusilla PI289628 (A10).

ethidium bromide and visualized under UV light to check for the presence of PCR products.

\section{DNA sequencing}

The PCR products of primer pairs a/b were recovered using the E.Z.N.A. Cycle Pure Kit, and DNA sequencing was performed on an $\mathrm{ABI}$ 3730XL sequencer using the primer a or b. 
Wang, C.T. et al.

\section{RESULTS AND DISCUSSION}

\section{Primary evaluation of the protocol}

All of the materials/treatments produced distinct bands of expected size on agarose gel (Figure 1). The PCR products resulting from 20, 40 or $60 \mu \mathrm{l} \mathrm{NaOH}$ treatment were all acceptable; therefore, in subsequent studies only the $60 \mu \mathrm{l}$ $\mathrm{NaOH}$ treatment was used. The concentration of the PCR templates prepared using $60 \mu \mathrm{l} \mathrm{NaOH}$ was around $3 \mathrm{ng} / \mu \mathrm{l}$.

\section{Further evaluation of the protocol}

All of the 11 peanut accessions (Table 2) gave good results, regardless of the starting materials. Clear bands were visualized on agarose gel, even with some wild accessions whose leaflets coated with thick cuticle. The bands were recovered and directly sequenced. Two of the trace files (partial) were shown in Figure 2 and Figure 3. The sequencing results verified that the PCR template preparation protocol was successful.

\section{CONCLUDING REMARKS}

To the best of our knowledge, this is the first report on high through-put preparation of PCR template in peanut. The present protocol was developed on the basis of the alkalilysis method as proposed by Wang et al. (1993) with some modifications. The boiling steps and the PVP component were included to ensure better and repeatable results.

Chenault et al. (2007) reported a non-destructive seed sampling method for PCR-based analysis with potential in marker assisted selection and transgene screeningin peanut, where as little as $20 \mathrm{mg}$ of peanut seed sample was enough for PCR template preparation; however, 20 steps are still needed. Using the present protocol, peanut DNA can be extracted in a relatively short period of time whenever a

Table 1. Peanut materials used for primary evaluation of the protocol.

\begin{tabular}{|c|c|c|c|c|}
\hline No. & Genotype & Leaflet & Primer pair & Treatment \\
\hline 1 & 18B4 & immature & TBPfex1, TBPrex1 & $40 \mu \mathrm{l} \mathrm{NaOH}$ \\
\hline 2 & L-1 & immature & TBPfex1, TBPrex1 & $40 \mu \mathrm{l} \mathrm{NaOH}$ \\
\hline 3 & Luhua 14 & immature & TBPfex1, TBPrex1 & $40 \mu \mathrm{l} \mathrm{NaOH}$ \\
\hline 4 & $6-33$ & immature & TBPfex1, TBPrex1 & $40 \mu \mathrm{l} \mathrm{NaOH}$ \\
\hline 5 & m5 & immature & TBPfex1, TBPrex1 & $40 \mu \mathrm{l} \mathrm{NaOH}$ \\
\hline 6 & 18B4 & immature & TBPfin2, TBPrin2 & $40 \mu \mathrm{l} \mathrm{NaOH}$ \\
\hline 7 & L-1 & immature & TBPfin2, TBPrin2 & $40 \mu \mathrm{l} \mathrm{NaOH}$ \\
\hline 8 & Luhua14 & immature & TBPfin2, TBPrin2 & $40 \mu \mathrm{l} \mathrm{NaOH}$ \\
\hline 9 & 6-33D3 & immature & TBPfin2, TBPrin2 & $40 \mu \mathrm{l} \mathrm{NaOH}$ \\
\hline 10 & L7-1 & immature & $a, b$ & $40 \mu \mathrm{l} \mathrm{NaOH}$ \\
\hline 11 & m5 & immature & $a, b$ & $40 \mu \mathrm{l} \mathrm{NaOH}$ \\
\hline 12 & L7-1 & field-grown & $a, b$ & $20 \mu \mathrm{l} \mathrm{NaOH}$ \\
\hline 13 & L7-1 & field-grown & $a, b$ & $40 \mu \mathrm{l} \mathrm{NaOH}$ \\
\hline 14 & L7-1 & field-grown & $a, b$ & $60 \mu \mathrm{l} \mathrm{NaOH}$ \\
\hline 15 & m5 & field-grown & $a, b$ & $20 \mu \mathrm{l} \mathrm{NaOH}$ \\
\hline 16 & m5 & field-grown & $a, b$ & $40 \mu \mathrm{l} \mathrm{NaOH}$ \\
\hline 17 & m5 & field-grown & $a, b$ & $60 \mu \mathrm{l} \mathrm{NaOH}$ \\
\hline
\end{tabular}

Note: The numbers used in the first column were the same as in Figure 1. 
Table 2. Peanut materials used for further evaluation of the protocol. (Primer pairs: a/b, treatment: $60 \mu \mathrm{NaOH}$ ).

\begin{tabular}{|l|l|l|l|l|}
\hline \multicolumn{1}{|c|}{ Identity } & \multicolumn{1}{|c|}{$\begin{array}{c}\text { Plant Introduction } \\
\text { No. }\end{array}$} & \multicolumn{1}{|c|}{ Species } & \multicolumn{1}{|c|}{ Section } & Botanical type \\
\hline GXAS* No. A 19 & 263133 & A. duranensis & Arachis & \\
\hline GXAS No. A2 & 338280 & A. stenosperma & Arachis & \\
\hline GXAS No. A14 & 331192 & A. correntina & Arachis & \\
\hline GXAS No.A8 & 210555 & A. villosa & Arachis & \\
\hline GXAS No. A7 & 219824 & A. monticola & Arachis & \\
\hline GXAS No. A10 & 289628 & A. pusilla & Heteranthae & \\
\hline GXAS No. A6 & 289639 & A. sp & Uncertain affinity & \\
\hline GXAS No. A13 & 289637 & A. sp & Uncertain affinity & \\
\hline Yingkousilihong (Landrace) & - & - & - & fastigiata \\
\hline Xingchengdahuasheng (Landrace) & - & - & - & hypogaea \\
\hline 1-4 (Silohong x A. glabrata) & - & - & - & - \\
\hline "GXAS: GaugXia & - & & \\
\hline
\end{tabular}

*GXAS: Gaungxi academy of agricultural sciences.

seed or a leaflet is available. It should be noted that although the ITS amplified in this report has high a copy number in plant genomes, this does not mean that the protocol is only suitable for DNA segments with high copy number. In fact, we have successfully cloned and sequenced partial fad 2 and conglutin genes using similar protocols (Wang et al. 2001; Wang et al. 2004).

In conclusion, we have developed a short protocol, suitable for high through-put preparation of PCR templates in peanut, with no genotypes proved recalcitrant thus far. Neither nitrogen treatment nor organic solvent is needed. It should not only save time and money, but also reduce the possibility of contamination. This protocol may find wide utility in PCR-based applications in peanut.

\section{REFERENCES}

BREVIARIO, Diego; BAIRD, W. Vance; SANGOI, Shail; HILU, Khidir; BLUMETTI, Pietro and GIANI, Silvia. High polymorphism and resolution in targeted fingerprinting with combined $\beta$-tubulin introns. Molecular Breeding, October 2007, vol. 20, no. 3, p. 249-259.

BUROW, Mark D.; SIMPSON, Charles E.; STARR, James L. and PATERSON, Andrew H. Transmission genetics of chromatin from a synthetic amphidiploid to cultivated peanut (Arachis hypogaea L.): broadening the gene pool of a monophyletic polyploid species. Genetics, October 2001, vol. 159, no. 2, p. 823-837.

CHEN, J.; HU, X.H.; MIAO, H.R.; CUI, F.G. and YU, S.L. Genomic DNA Extraction with CTAB method and its use for SSR and SRAP. Journal of Peanut Science, 2008, vol. 37, no. 1, p. 29-31.

CHENAULT, K.D.; GALLO, M.; SEIB, J.C. and JAMNE, V.A. A non-destructive seed sampling method for PCRbased analysis in marker assisted selection and transgene screening. Peanut Science, January-June 2007, vol. 34, no. 1, p. 38-43.

CHOI, K.; BUROW, M.D.; CHURCH, G.; BUROW, G.; PATERSON, A.M.; SIMPSON, C.E. and STARR, J.L. Genetics and mechanism of resistance to Meloidogyne arenaria in peanut. Journal of Nematology, September 1999, vol. 31, no. 3, p. 283-290.

KOCHERT, G.; HALWARD, T.; BRANCH, W.D. and SIMPSON, C.E. RFLP variability in peanut (Arachis hypogaea L.) cultivars and wild species. Theoretical and Applied Genetics, May 1991, vol. 81, no. 5, p. 565-570.

SARWAT, Maryam; NEGI, Madan; LAKSHMIKUMARAN, Malathi; TYAGI, Akhilesh; DAS, Sandip and SRIVASTAVA, Prem. A standardized protocol 
Wang, C.T. et al.

for genomic DNA isolation from Terminalia arjuna for genetic diversity analysis. Electronic Journal of Biotechnology, 2006, vol. 9, no. 1, p. 85-90.

WANG, C.T.; YANG, X.D.; JIANG, Y.; ZHANG, J.C. and CHEN, D.X. A simple pretreatment procedure for direct PCR using immature leaves from peanut kernels. Journal of Peanut Science, 2001, vol. 30, no. 3, p. 30-31.

WANG, C.T.; HUANG, Y.; YANG, X.D.; JIANG, Y.; ZHANG, J.C.; CHEN, D.X.; MIN, P. and YU, S.L. Isolation of DNA from peanut: comparison between modified CTAB and high salt, low pH methods. Journal of Peanut Science, 2002, vol. 31, no. 3, p. 20-23.

WANG, C.T.; YANG, X.D.; JIANG, Y.; CHEN, D.X.; ZHANG, J.C.; LIU, G.Z. and YU, S.L. Novel method to obtain peanut DNA of interest based on available sequence information. Journal of Peanut Science, 2004, vol. 33, no. 3, p. 15-17.

WANG, Hong; QI, Meiqing and CUTLER, Adrian J. A simple method of preparing plant samples for PCR. Nucleic Acids Research, August 1993, vol. 21, no. 17, p. 41534154.

WANG, Jian Bo; ZHANG, Wen Ju and CHEN, Jia Kuan. Application of ITS sequences of nuclear rDNA in phylogenetic and evolutionary studies of angiosperms. Acta Phytotaxonomica Sinica, July 1999, vol. 37, no. 4, p. 407416.

WEISING, K.; NYBOM, H.; WOLFF, K. and KAHL, G. DNA fingerprinting in plants: principles, methods and applications. $2^{\text {nd }}$ ed. Taylor and Francis Group, 2005. 338 p. ISBN 0-8493-1488-7.

ZIEGELIN, G.; FÜRSTE, J.P. and LANKA, E. TraJ protein of plasmid RP4 binds to a 19-base pair invert sequence repetition within the transfer origin. Journal of Biological Chemistry, July 1989, vol. 264, no. 20, p. 1198911994. 